\title{
A multinational comparison of care-leaving policy and legislation
}

\author{
Benjamin Strahl ${ }^{\mathrm{a}}$ (D), Adrian Du Plessis van Breda ${ }^{\mathrm{b}}$, Varda Mann-Feder $^{\mathrm{c}}$ and Wolfgang Schröer ${ }^{\mathrm{a}}$ \\ ${ }^{a}$ Institute for Social and Organizational Pedagogy, University of Hildesheim, Hildesheim, Germany \\ ${ }^{\mathrm{b}}$ Department of Social Work, University of Johannesburg, Johannesburg, South Africa \\ ${ }^{c}$ Department of Applied Human Sciences, Concordia University, Montreal, Canada \\ Email: strahl@uni-hildesheim.de
}

(Received 16 June 2020; revised 12 August 2020; accepted 14 September 2020)

\begin{abstract}
Care-leavers - those transitioning from alternative care towards young adulthood - are widely recognized as a vulnerable population, yet child protection legislation seldom applies to them because they have reached adulthood. Despite this, little internationally comparative research on care-leaving policy and legislation has been conducted. This paper maps multinational policy and legislation and its impact on the services to careleavers and the challenges they experience. An online survey was conducted with key informants in 36 countries and analysed by a multinational team of care-leaving scholars. Findings reveal that few countries have well-developed care-leaving legislation. Most countries provide little aftercare beyond the age of 18 , even when legislation provides for it. Within the context of suboptimal social policy and limited aftercare services, findings also reveal high vulnerability among care-leavers. Recommendations for policy development, global dialogue, further research and advocacy are proposed.
\end{abstract}

Keywords: Leaving care; youth transitions; social policy; legislation; emerging adulthood

\section{Introduction}

Care-leavers constitute a population of young people aged about 18 to mid-20s - roughly equivalent to Arnett's (2019) stage of Emerging Adulthood - who are or have transitioned out of alternative care (also termed out-of-home) placements, including kinship care, foster care and residential care. Having reached the age of majority, these young people are no longer considered to be children and thus usually no longer benefit from the protection of child welfare policy and legislation. Yet, research has consistently shown this population to be at significantly greater risk for negative outcomes than youth who have grown up in and transitioned out of their own families, in relation to education, well-being and involvement in crime and substance abuse (eg. Mann-Feder \& Goyette, 2019; Mendes \& Snow, 2016; Van Breda, 2018).

The capacity of the state to facilitate the transition of care-leavers into productive adult living typically defined by markers such as employment, financial independence, home ownership, marriage and children - is dependent on national policy and legislation that addresses the unique needs of this population. As stated by Pinkerton and Van Breda (2019, p. 88), "social policy provides the necessary scaffolding and strategic direction to enable appropriate and cost-effective service delivery during the transition from out-of-home care towards adulthood. Services without enabling policy are vulnerable to lack of coherence and direction, fragmentation and under-resourcing."

There has been limited research that demonstrates the ways in which shifts in national policy and legislation over time impact on the lives of care-leavers. For example, Storø (2015) tracked Norwegian care-leaving policy over a 100 -year period through three distinct stages that were linked to revised 
legislation, which in turn had profound impacts on experiences of transitioning out of care. Other studies have compared policy and legislation across two or more countries, to expose differences in social policy and demonstrate how these differences have impacted on the lives of care-leavers. Storø, Sjöblom, and Höjer (2019) and Backe-Hansen et al. (2013), eg., provided comparative analyses of the welfare systems in Sweden and Norway and the ways differences in welfare policy impact on care-leavers regarding access to family support services, limitations on who can and cannot receive care-leaving services and whether care-leaving services are specialized or part of regular services for all youth. Most recently, Mendes and Rogers (2020) examined the implications of extended care programmes in the United States and the United Kingdom for similar initiatives in Australia. Bond (2018) compared South Africa's relatively underdeveloped legislation with that of the United Kingdom, the United States and Australia. She argued from a social justice perspective for better policy and legislation to care for youth whom the state had removed from parental care.

Despite the call for changes to social policy and legislation, relatively little is known about the availability and rigour of policy and legislation for care-leavers on an international scale. Studies that undertake comparative analysis, such as those discussed above, typically compare only a few countries, and most have focussed on countries in the Global North, Bond (2018) being a rare exception. Thus, the global trends regarding care-leaving policy and legislation are relatively unknown, nor is it clear how these impact on the lives of care-leavers during their struggle to become "adults."

This article aims to map care-leaving policy and legislation and its impact on selected aspects of careleavers' experiences across 36 countries spread across both Americas, Europe and Asia, Africa and Australia. A mixed-methods survey was conducted with key informants in each country. This paper provides a review of literature on multinational comparative research on care-leaving, our methodology and our findings in relation to three foci: multinational policy and legislation, services for care-leavers and the challenges faced by them. The article concludes with a discussion of the findings and conclusions about the state of global care-leaving policy.

\section{Review of literature}

An overview of the global research landscape reveals that there are many studies on leaving care. Marion and Paulson (2019), in their review of the literature, stated that there has been a recent upsurge in interest in youth leaving care, as well as an increase in scholarly articles. They found 64 research articles published in peer-reviewed academic journals during the period from January 2015 to October 2016 alone. Their "analysis of research questions and future research directions resulted in four main topics areas [sic]: (1) policy, program and services; (2) transition trajectories and markers; (3) social network [sic] and social support and (4) subpopulations" (pp. 108-109). Although some of the articles identified involved researchers from different countries or even participants from different countries, international comparisons were not strongly represented.

The International Research Network on Transitions to Adulthood from Care (INTRAC) is a global community of researchers dedicated to the promotion of national and international research on careleaving and the transition from care to adulthood. INTRAC has supported cross-national research on care-leaving for many years and produced a series of collected works with an international perspective (Mann-Feder \& Goyette, 2019; Mendes \& Snow, 2016; Stein \& Munro, 2008). These books, featuring international research, policy and practice on the transitions of young people out of care, are, however, usually approached as collections or compilations of care-leaving research in different countries, rather than presenting work that truly compares care-leaving across several countries.

In addition to the presentation of country-specific issues, there are publications that deal with generic issues in relation to care-leaving. However, these tend to be theoretically oriented and therefore are not focussed on care-leaving in the context of different countries. These publications concern young people who are transitioning from alternative care in general. For example, articles not tied to specific countries address developmental theory (Mann-Feder, 2019), social networks (Goyette, 2019), resilience (Gilligan, 
2019; Pinkerton \& van Breda, 2019) and human rights (Munro, 2019). A generic approach also characterizes some internationally oriented articles featuring research on specific sub-groups of careleavers (eg. disabled young people, young people with mental health problems, indigenous youth and young offenders) or on specific topics of interest, such as education. The question of educational disadvantage and pathways to educational success has been the focus of several international research projects. These studies found similar educational challenges and barriers across countries (eg. Jackson \& Cameron, 2012; O’Higgins, Sebba, \& Gardner, 2017; Refaeli \& Strahl, 2014).

Multinational comparative research is hampered by a lack of consensus regarding the construction of the phenomena being studied. Pinkerton (2008, p. 245), eg., summarized research, policy and practice for 16 countries and stated that "while information may be accessible, it may not be reliable or comparable across jurisdictions." He therefore concluded that for comparative work to be undertaken, a conceptual model or framework had to be developed to provide a basis for specific questions. Ward (2008, p. 276) noted that "the different ways that different societies balance the responsibilities of the individual, the state and the family are reflected in the development of child and youth welfare legislation and policy" (p. 276). Van Breda and Pinkerton (2020) have argued and illustrated that these challenges are particularly pronounced when comparing Global North and Global South countries.

These differences between countries in welfare systems, in the construction of childhood and adulthood and the transition between them, make international comparisons of care-leaving difficult (Cameron et al., 2018). Prior to making comparisons, an agreement would be required regarding terminology, basic concepts and shared understandings of what is under investigation. Stein (2008), summing up the challenges of international research and ways to improve outcomes using international samples, came to a similar conclusion, emphasizing that a major challenge would be to identify foci for future comparative work in order to "understand the impact of local, national and global processes upon" care-leavers' lives (p. 306).

Some subsequent research has responded to these conclusions by narrowing the focus and pursuing precisely defined research questions across a limited number of countries. For example, Stein and Dumaret (2011) explored the research evidence from France and England on the mental health of young people aging out of care into adulthood. Set in the legal, policy and service framework for both countries, they reviewed evidence on the increased risk of mental and physical problems at the time of aging out of care and suggested that interventions across the life course of young people are needed. Similarly, based on Pinkerton's (2008) model for international comparison using the macro, mezzo and micro domains, Munro, Mølholt and Hollingworth (2016) compared the welfare regimes of the United Kingdom and Scandinavia to explore the impact on the transitions of young people leaving care. They found that even though national differences were apparent in relation to both policy and the services available, careleavers in both countries experienced accelerated and compressed transitions. The authors explained this finding by naming a potential mismatch between the services and supports offered and the actual wishes of young people. Thus, the options available for the young people were limited or did not seem relevant to them.

A larger body of work on international comparisons does exist in relation to young people who are still in care. This is due to the greater availability of official data on young people in care than for young people aging out of care or for those who have already left. Ubbesen, Gilbert, and Thoburn (2015), for instance, identified that differences between England and Denmark could be found when comparing common trends, such as the age at which children enter care. The authors stated that:

entry into out of home care during adolescence was more common in Denmark than in England. By age 16, the cumulative incidence of ever entering out of home care during childhood was twice as high in Denmark (33.83/1,000) as in England (15.62/1,000). (p. 63)

These trends diverged over time, and the authors concluded that this could have reflected the changing policies in the two countries. The reality of changing policies in one country and differences within regions (eg. because of federal structures) as well as "the impact of supra-national regional 
structures such as the European Union" (Pinkerton, 2008, p. 246) makes comparative work even more complicated.

When reviewing international comparisons, it is striking that the focus is usually limited to the Global North. Most of the countries under study are European countries, although Australia, Canada and the United States are often included. It is rare for African, South American or Asian countries to be included in such studies (Van Breda \& Pinkerton, 2020). O’Higgins et al. (2017, p. 199), eg., deliberately excluded countries from the Global South, stating, "Only high-income countries were considered because children's services and foster care operate in broadly similar contexts in these countries." The few international articles that do integrate countries from other regions of the world (eg. Argentina with England and Northern Ireland in Kelly, Dixon, and Incarnato, 2016 or China with Israel, Germany and Switzerland in Keller et al., 2016) do not focus on international comparisons of policy or practice but on methodological issues and research access to the field. In summary, comparative multinational studies tend to refer to selected or relatively few countries and lack a global perspective.

\section{Methods}

This study employed an online, mixed-methods survey to query international care-leaving policy and practices. It was conceived and executed by four researchers from Germany, South Africa and Canada who were brought together by their activities on behalf of INTRAC and who had identified the importance of a data-based approach to promote worldwide advocacy for youth leaving care. Participants were recruited through two international associations: the International Federation of Educative Communities (FICE) and the Africa Network of Care-Leaving Researchers (ANCR). In both cases, membership in these voluntary associations consists of country representatives, who have direct knowledge of child welfare and care-leaving in their respective countries. In FICE, most country representatives are directors or senior managers in frontline child welfare agencies, while in ANCR, representatives are all active care-leaving researchers.

An online survey was created using SoSci Survey that included 35 items spanning five major topic areas: general information about each country; provisions and logistics for the administration of general child welfare policy; care-leaving legislation and policy; programmes and entitlements for care-leavers and current challenges characteristic of care-leavers in each country. The survey comprised multiple choice and open-ended questions, and in some topic areas, respondents were also asked to provide a rating on a Likert scale, so that the questionnaire generated a range of quantitative and qualitative results. The survey was administered in English, which is the operating language of both participating associations. Prior to finalizing the survey, it was pilot tested at an INTRAC meeting with three volunteer researchers from different countries who provided feedback to improve readability and clarity.

In March 2018, an email invitation was sent to all country representatives of FICE inviting them to participate in the survey. One of the FICE members represents the West Africa region, which comprises several countries. Their data are nevertheless included, and "West Africa" is enclosed in scare quotes to indicate that this is not a country. Rates of participation were monitored regularly, and a reminder was sent in September 2018. At that time, ANCR joined the study to increase representation from the Global South, and all members were sent a link to the survey. The survey was closed in January 2019. Twenty-six of the 39 FICE countries participated, totalling 67 per cent of the membership. For ANCR, 10 out of 11 member countries, or 91 per cent, participated. These return rates are considered extremely high for an online survey (Harzing, Reiche, \& Pudelko, 2013). Figure 1 provides both a map and a list of the participating countries.

The data were exported from SoSci Survey to SPSS v26 for analysis. The quantitative statistics generated were primarily descriptive in nature. The responses to the qualitative items on the survey were analysed using thematic content analysis.

We judged that this study involved minimal risk in relation to research ethics because the subject matter was not personal to participants, who acted as key informants on behalf of their countries in their 


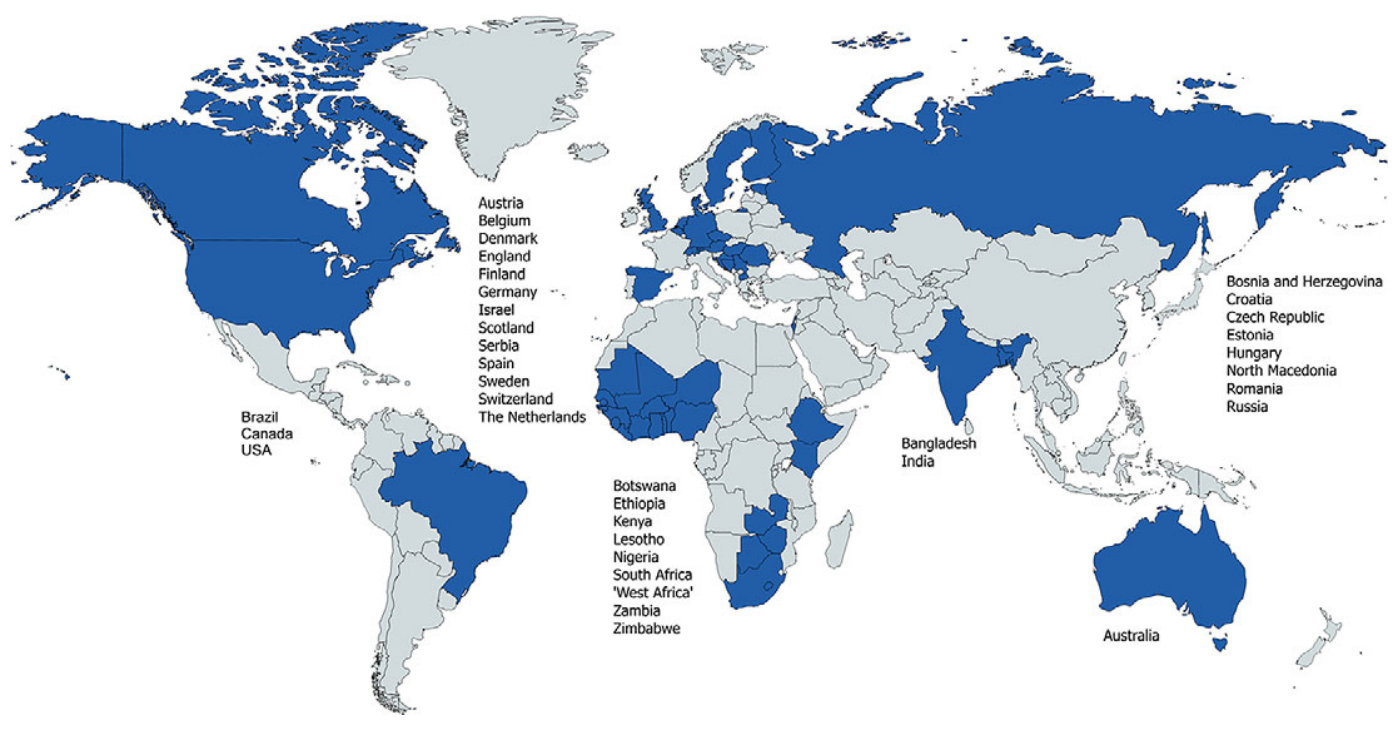

Figure 1. Map of study countries (and the West Africa region).

function as practitioners, managers or researchers. The administration of FICE provided an email list of members to the research team, and an information letter was emailed to all of them, allowing those invited to participate or not as they saw fit, without being required to respond. The organiser of ANCR is a member of the research team and sent out a general invitation to all ANCR members through the network's listserv, enabling prospective participants to freely choose whether they wished to participate. No pressure was exerted on participants to complete the survey, and no incentives were offered for their participation. Completion of the survey was considered to constitute consent to participate. Ethics approval for the study was provided by the University of Hildesheim, Germany.

\section{Results}

The results are divided into three sections. First, we report on the extent of legislation in relation to the provision of care and aftercare (or care-leaving) among the 36 countries, to provide an understanding of international policy framework within which young people leave care. Second, we address several resulting facets of these policy differences, in relation to the age of leaving care and services provided to care-leavers. Last, we focus on the challenges that care-leavers confront in the transition towards adulthood across our international sample.

\section{Care-leaving policy and legislation}

Legislation, which is a formal expression of social policy, was a key focus of the survey. Participants were asked a series of questions about their country's legislation, the results of which are presented in Figure 2. Working down Figure 2 from the top row, of the 36 countries in the study, 32 (89 per cent) reported that they did have legislation that addressed children in care, eg.: the mechanisms by and the grounds on which children may be removed from parental care and placed in alternative care; the services that should be provided to children while in care and the rights of families of looked-after children. Of these 32 countries, 23 (constituting 64 per cent of the total sample and 72 per cent of those having in-care legislation) judged their country's legislation to be "well-developed" rather than "rudimentary."

Only 17 country participants ( 47 per cent of the total sample) reported having legislation addressing care-leavers after leaving care and/or aftercare services, roughly half the number of countries with 


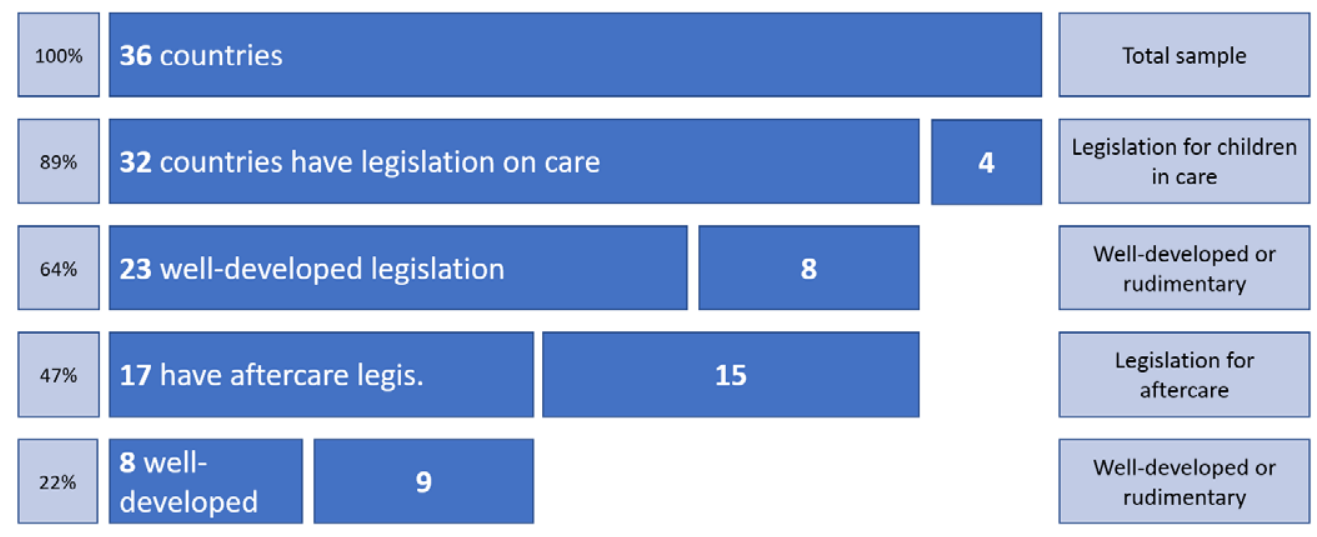

Figure 2. Legislation for care and aftercare.

legislation addressing children in care. All the countries reporting no legislation on children in care also had no legislation on care-leavers. Only 8 of the 17 countries with aftercare legislation ( 22 per cent of the total sample and 47 per cent of those with aftercare legislation) reported that the aftercare legislation was "well-developed" rather than "rudimentary."

Table 1 lists the level of development of both care-related and aftercare-related legislation for all 36 countries in the sample.

These findings point to decreasing rates of legislative protection as young people transition from care to young adulthood: the number of countries reporting any legislation drops by about half from legislation for children to legislation for care-leavers, and the rigour of this legislation drops from two thirds for children in care to one half for care-leavers. Thus, while two thirds of countries have welldeveloped legislation for children who are placed into alternative care, only one fifth have well-developed legislation for these children after they leave care.

\section{Care-leaving services}

The decreasing rate of legislative protection as young people transition from care to young adulthood impacts the age up until which young people can rely on support through child and youth welfare systems. Participants were asked to identify the age up to which support is officially available (according to policy or legislation) as well as how this works in practice (see Figure 3). The results show that considerable differences exist between the official ages at which care ends and the actual ages at which young people leave - young people tend to leave care at an earlier age than legislation actually permits.

One fifth of the countries ( 7 countries, 19 per cent) report that support is officially available up to the age of 25 or even 27 years, according to policy or legislation, and a further five countries (14 per cent) report that it is available up to the age of 22-24 years. One quarter ( 9 countries, 25 per cent) report that legislation permits remaining in care up to age 21 , which in some countries is the age of majority. In slightly less than half of the countries ( 15 countries, 42 per cent), support is officially granted until the age of 18 years, which is widely regarded as the age of legal adulthood.

However, the legal right to remain in care does not always translate into practice. Figure 3 shows that in all age groups above 20 years, the number of countries where care-leavers are supported in practice falls below the number of countries where support is available according to legislation. While seven countries officially allow support up to the age of 25-27 years, only three report that support extends to that age in practice. This also applies for the age groups $22-24$ years and 21 years. For each, just three country representatives specify that young people are supported to those ages in practice, even though five and nine countries, respectively, officially offer support to those ages. By contrast, two thirds of the countries ( 24 countries, 66 per cent) report that support ends in practice at the age of 18 years or below, 
Table 1. Legislation for care and after care per country.

\begin{tabular}{|c|c|c|c|}
\hline & Well-developed legislation & Rudimentary legislation & No legislation \\
\hline \multirow[t]{23}{*}{ Legislation on care $^{a}$} & Australia & Bosnia and Herzegovina & Bangladesh \\
\hline & Austria & Canada & Botswana \\
\hline & Belgium & Kenya & Ethiopia \\
\hline & Brazil & Nigeria & Lesotho \\
\hline & Croatia & North Macedonia & \\
\hline & Czech Republic & Switzerland & \\
\hline & Denmark & "West Africa" & \\
\hline & England & Zambia & \\
\hline & Estonia & & \\
\hline & Finland & & \\
\hline & Germany & & \\
\hline & Hungary & & \\
\hline & India & & \\
\hline & Israel & & \\
\hline & Romania & & \\
\hline & Russia & & \\
\hline & Scotland & & \\
\hline & Serbia & & \\
\hline & South Africa & & \\
\hline & Spain & & \\
\hline & Sweden & & \\
\hline & The Netherlands & & \\
\hline & USA & & \\
\hline \multirow[t]{11}{*}{ Legislation on aftercare } & Australia & Belgium & Austria \\
\hline & Denmark & Estonia & Bosnia and Herzegovina \\
\hline & England & Hungary & Brazil \\
\hline & Finland & North Macedonia & Canada \\
\hline & India & Russia & Croatia \\
\hline & Romania & Serbia & Czech Republic \\
\hline & Scotland & South Africa & Germany \\
\hline & USA & Spain & Israel \\
\hline & & "West Africa" & Kenya \\
\hline & & & Nigeria \\
\hline & & & Sweden \\
\hline
\end{tabular}


Table 1. Continued

\begin{tabular}{lll}
\hline Well-developed legislation & Rudimentary legislation & No legislation \\
\cline { 2 - 2 } & Switzerland \\
\hline & The Netherlands \\
\hline & Zambia \\
\hline
\end{tabular}

${ }^{a}$ Zimbabwe data missing.

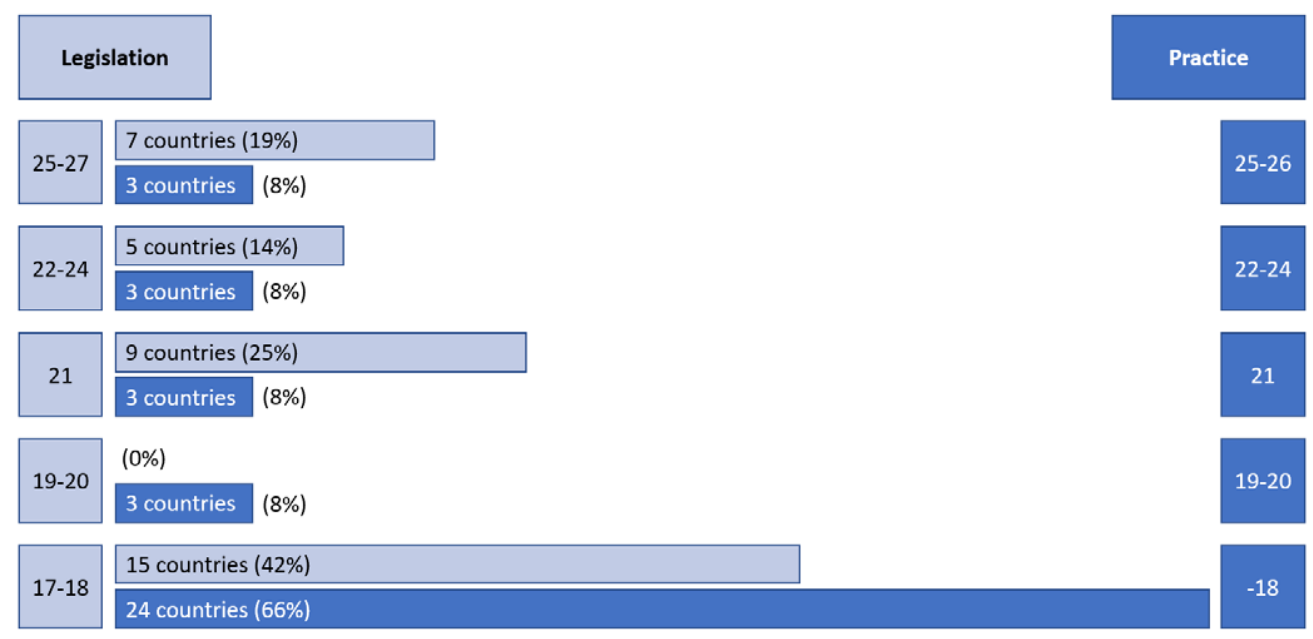

Figure 3. Age up to which young person may remain in care according to legislation and practice.

even though fewer than half the countries ( 15 countries, 42 per cent) limit support to 18 years. In short, nine countries that legally permit young people to remain in care beyond 18 do not actually allow them to remain in care beyond 18 .

The reasons for the differences between official and practical support were not queried in the survey and need to be further investigated. We could thus find nothing in the data to explain ending support earlier than legally provided. It may be that whether legislation makes extended care mandatory or discretionary may account for this difference. In Germany, Croatia, England and Hungary and others, support is officially available up to age 24 and even beyond, but in practice, support is only provided until age 18. Conversely, Ethiopia, Czech Republic, Lesotho, Israel and Russia support care-leavers in practice until 23 years and older, even though policy and legislation expect support to end earlier. It seems, therefore, that there is little congruence between legislative or policy limits for remaining in care and the actual age up until which care-leavers remain in care.

In addition to the age limit of support, country participants were asked to specify what services, if any, were offered after leaving care (see Figure 4). Two third of the countries (24 countries, 66 per cent) provide aftercare support, even though only 17 countries ( 47 per cent) have a legal framework addressing care-leavers after leaving care and/or aftercare services. In other words, seven countries offer aftercare services, despite not having legislation mandating or supporting these services.

Country participants were also asked to indicate the nature of support from the following options: support for education/employment, general counselling, supervised/semi-independent living, attendance at a care-leaver centre, problem-specific counselling (eg. debts, housing), therapeutic support and a "coming back" option. The survey did not specify if these aftercare services were provided to all youth 


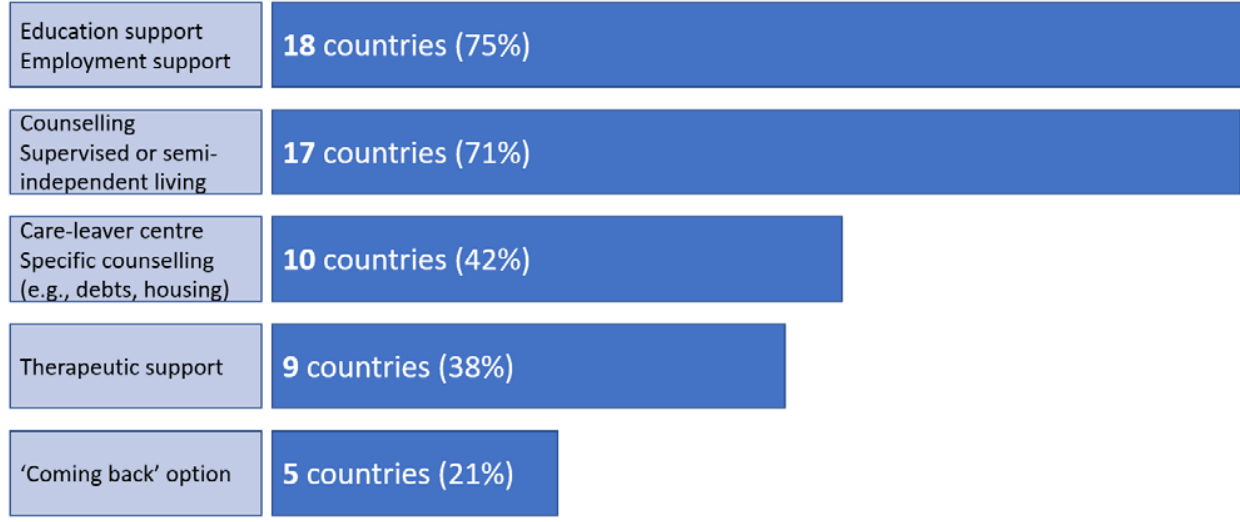

Figure 4. Aftercare services offered to care-leavers. 24 of the 36 countries provided data for this analysis.

or were specific to care-leavers only. In addition, there is no indication if services are limited by location, exist only as small projects or are accessible everywhere and anytime for all care-leavers.

Figure 4 illustrates the availability of different services offered to care-leavers. Where services do exist, a major emphasis is the provision of support to increase access to the labour market because education/ employment services are offered by 18 of 24 countries with aftercare services ( 75 per cent). This is closely followed by support services without a specific problem focus: counselling and supervised or semiindependent living options are available from aftercare services in 17 countries ( 71 per cent). Care-leaver centres that provide a point of contact are less frequent, available in 10 countries ( 42 per cent), at the same rate as the provision of counselling opportunities related to problem-specific challenges, such as managing debt or housing problems. Therapeutic aftercare support is offered in nine countries (38 per cent), and the "coming back" option - the possibility of moving back into care after leaving care even at an older age - is available in only five countries (21 per cent).

An inspection of individual country data reveals a close association between legislation and provision of aftercare services. All countries with a well-developed aftercare legislative framework offered aftercare services for care-leavers. Furthermore, countries with well-developed legislative frameworks tend to offer a broader range of services than countries with less well-developed legislation. For example, three countries with well-developed aftercare frameworks - England, Denmark and Scotland - all indicated a range of aftercare services. In countries with a rudimentary legal framework on aftercare, services are often available, but there are also exceptions. For example, participants from South Africa and "West Africa" reported that virtually no formal services exist, even though a rudimentary aftercare legislation exists. And in countries without any legal framework on aftercare, services to care-leavers are mostly not offered, as one might expect. However, one third of the countries without aftercare legislative frameworks (five out of 15 countries, viz. Canada, the Czech Republic, Germany, Israel and the Netherlands) report that aftercare services do exist. As with the age of leaving care, legislative frameworks and services to care-leavers do not align perfectly.

In addition to these formal services offered to care-leavers, care-leavers themselves are increasingly organizing and forming self-help and advocacy groups. This is in part a response to their lack of entitlements and their increasing efforts to fight for themselves. These organizations are known by different names in different parts of the world, eg. youth advisory boards in the United States (Havlicek, Lin, \& Braun, 2016), youth in care networks in Canada (Raychaba, 1989), societies of care-leavers in Africa (KESCA, 2015) and care-leavers' associations in Europe. These care-leaver associations provide "a conduit or instrument through which young people can talk about their experiences of being in care, feel supported by peers and professionals and have their opinions taken into account in policy discussions and service delivery" (Evans, 2013, p. 63). Our survey collected data on the existence of these groups in the participating countries and queried the sources of funding available to support their work (see Figure 5). 


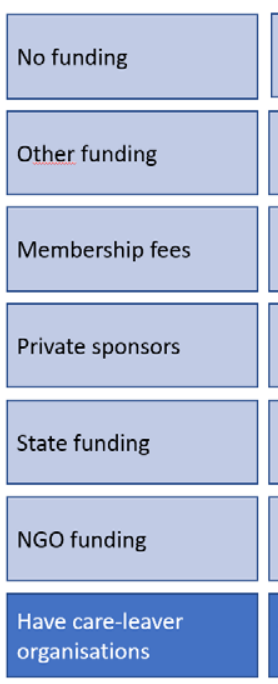

15 countries $(79 \%)$

Yes: 19 countries $(53 \%)$

Figure 5. Existence and funding of care-leaver organizations.

Figure 5 illustrates that 19 out of 36 countries (53 per cent) reported having active care-leaver associations. All these associations are reported to rely on multiple sources of funding, and nowhere are they wholly supported by government. Of these 19 countries, 15 (79 per cent of countries with care-leaver associations) reported that some funding came from NGOs, 10 (53 per cent) reported that some funding came from government, 8 (42 per cent) referred to private funders and 2 ( 11 per cent) referred to other unspecified sources of funding. Two countries reported that care-leaver associations receive no funding whatsoever. It seems clear that all the identified care-leaver associations cannot rely on a guaranteed budget from any one source. At the same time, 13 countries (36 per cent) reported that they have no careleaver associations, and a further four country participants (11 per cent) did not know if such an association existed.

\section{Challenges faced by care-leavers}

Given the limited availability of support for young adults, evidenced by the absence of aftercare legislation in most countries and the underutilization of options that exist formally, it is no big surprise that care-leavers worldwide face substantial challenges (see Figure 6). Respondents were asked to identify the challenges young adults face after leaving care. They could choose from a list of the most common difficulties derived from international research, using a Likert scale to indicate if they "strongly agree," "agree," "disagree," "strongly disagree" or "I do not know." The problem areas which were suggested included housing, eg. instability in living places and homelessness; employment; poverty; involvement in anti-social behaviours, like using drugs and delinquency; mental health; education; isolation/loneliness and teenage parenthood.

Since in most of the countries in our sample, there are no official statistics or research findings in relation to care-leavers' challenges, our findings reflect the views of our respondents and should be viewed as estimates based on their professional experience.

Figure 6 shows that most participants agreed or strongly agreed that all of the challenges listed were faced by care-leavers in their country. The findings suggest that employment is the main challenge for care-leavers, being reported by all but two of the countries surveyed ( 34 countries, 94 per cent). Not far behind, education, housing and poverty were perceived as main challenges in 31 countries (86 per cent). Isolation or loneliness was observed as a challenge in 29 countries (81 per cent) and mental health in 27 countries ( 75 per cent). Delinquency and substance abuse were reported in 22 countries (61 per cent) 


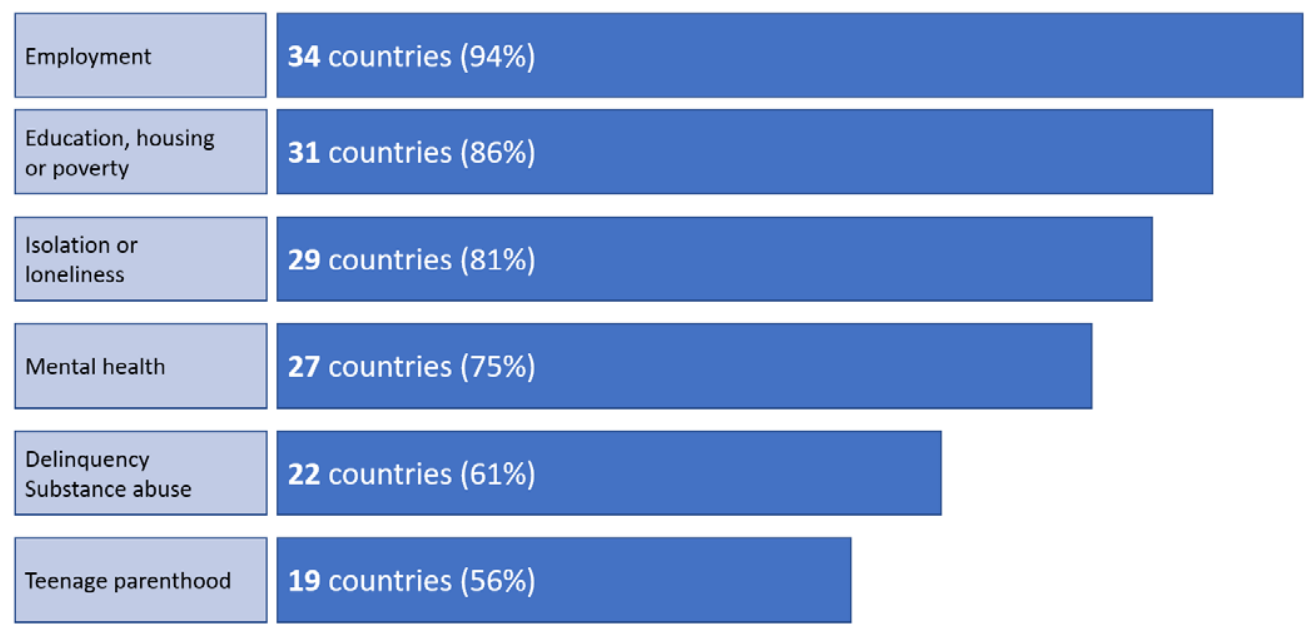

Figure 6. Challenges faced by care-leavers.

and teenage parenthood in 19 countries (56 per cent). These last two are less commonly reported as main challenges, although they are still observed in more than half of the countries.

Almost half of the country participants ( 17 countries, 47 per cent) agreed or strongly agreed to eight or nine of the nine challenges. This includes Australia, Austria, Belgium, Botswana, Brazil, Canada, England, Ethiopia, Finland, Hungary, India, Kenya, Lesotho, Nigeria, Romania, "West Africa" and Zambia. Six or seven of the nine challenges were selected in nearly one third of the countries (11 countries, 31 per cent), viz. Bosnia and Herzegovina, Croatia, Estonia, Scotland, South Africa, Spain, Switzerland, the Netherlands, the United States and Zimbabwe. In six countries (17 per cent), only three to five challenges were agreed on, namely Czech Republic, Germany, Israel, North Macedonia, Russia and Serbia. There were only two countries in which very few challenges were identified by the country participants: in Bangladesh, only unemployment was seen as a main challenge for care-leavers and in Denmark no main challenges were reported at all for care-leavers.

\section{Limitations}

International online surveys share some general limitations. In providing the survey in only one language, there may be a language bias that impacted the results, particularly as it has been observed that there can be a "lack of the respondent's confidence in responding in a non-native language" (Harzing et al., 2013, p. 17). Given this concern, it may have been advisable to test the questionnaire with native speakers from each of our participating countries.

Our survey did not interrogate the qualifications of the respondents. Eligibility to participate only required being a country representative to FICE or an ANCR member, and it is unclear if the respondents all had current and accurate knowledge of care-leaving in their country. Some countries submitted multiple survey responses because, in some cases, the FICE mailing list had multiple names for one country. In these cases, the research team consulted an INTRAC member who was recognized as a scientific expert on leaving care research of the respective country to advise on discrepant responses by multiple country respondents. It also became clear that some of the questions, particularly those that required rankings, were highly subjective in nature and should have been accompanied by specific definitions. A good example of this is that participants were asked to choose whether their child welfare legislation was comprehensive or rudimentary.

Perhaps most significantly, it became clear after the results were analysed that there may have been discrepancies in the terminology used to describe child welfare practice, such that the questions may not 
have always had the same meaning in different countries. Other authors have pointed to the overall complexities of international comparative work stating that "consideration needs to be given to differences in the historical, social, cultural, political and economic context that influence social policy development" (Munro \& Stein, 2008, p. 12). Cross-national research involves "culture-specific attributes and meanings which need to be explicitly taken into account to ensure sound interpretation" (Reiche \& Harzing, 2007, paragraph 2). Countries in this study seem to differ in the framing of alternative care and aftercare and even in who should be referred to as a care-leaver. An important aspect of future crossnational studies would be the provision of a glossary, so that participants are clear on the meaning of the terms used in the survey.

In addition to these issues, there are difficulties that are specific to comparative work on care-leavers per se. Differences in various countries can be found with regard to definitions, terminology and language; legal and policy frameworks, as well as administrative structures, and the quality and availability of official data and research evidence (Courtney, 2008; Pinkerton, 2008; Stein, 2008; Ward, 2008). Other major reasons cited to explain the paucity of international comparative work on careleaving are difficulties with the accessibility of information (Pinkerton, 2008) and the diversity of understandings regarding the population in out-of-home care in general (Ward, 2008). For international comparisons, it may be more fruitful to develop a common framework for datasets, which predefines crucial concepts and terms.

Finally, this study suffers from the absence of the perspectives of care-leavers as a counterpoint to the views of our key informants. These data represent responses from experts and are not based on an insider view of the everyday life of care-leavers in different countries. It is useful that some of the experts are aware of and can refer to the self-organization of care-leavers in their countries; however, this does not ensure that the rights and voices of care-leavers are respected and that their well-being and participation are promoted at local or national levels.

\section{Discussion and conclusion}

This study is a just a beginning. It confirms that care-leaving is a transnational and global challenge in relation to social policy, legislation and services in supporting the transition to adulthood from care. This comparison points out the differences in the legal and social regulations and the considerable social challenges confronting care-leavers worldwide. The results highlight some tragic ironies: despite the many difficulties care-leavers face, they have access to relatively few services and even fewer legal entitlements, which in some cases are not even actualized in practice. The overwhelming majority of youth in the transition from care to adulthood in the countries in our sample are left to survive on their own at age 18 or younger, even when legislation makes provisions for them to stay in care longer. Even where services do exist, a consistent finding across the globe is the challenge that care-leavers face in finding employment and establishing economic stability. It is perhaps because of the gaps in services and entitlements that the care-leaver movement has been gaining traction around the world, as is also documented by this study.

Walther's (2016) life course transition regimes may be useful in making sense of the findings. One critical matter is the age range during which care-leaving takes place. In this study, most countries reported that aftercare support ends between the ages of 16 and 18, while in some other countries, aftercare services are provided well into the mid-20s. These disparities may be attributable to the differences in institutional structures related to the transition to adulthood in these countries, but this still does not fully explain the huge inequities in the levels of support that are provided in different places. Similar countries in Europe have different regulations related to the age at which support ends for careleavers. Even the research that sensitized practitioners and policy makers to the extended requirements for support in the normative population of what we now refer to as Emerging Adults (Arnett, 2019) has not had a systematic influence on the development of support structures and legal regulations for careleavers everywhere. Furthermore, a postcolonial perspective on transition regimes and young adulthood 
has not been developed (Van Breda \& Pinkerton, 2020); this remains an important future task for careleaving research and theorization.

This study shows that the differences between countries in relation to legal and social regulations are enormous. Some countries have well-developed legislation and aftercare frameworks, while others have none. Even within aftercare services, the disparities are substantial. While some offer an impressive range of services, other countries provide only very basic or poorly defined services. Although this extends beyond the scope of this study, one might speculate that the range of challenges care-leavers face in different countries may reflect the availability and adequacy of aftercare services. It is well documented in the positive youth development literature that the capacities of individual youth explain only a small amount of the variance in young adult outcomes (Sanders \& Munford, 2014). In fact, the availability of appropriate services has a dramatic impact on whether young people thrive or falter, such that "the social ecology that surrounds vulnerable youth is as important as the particular characteristics of the young person in terms of creating potential for change" (Sanders \& Munford, 2014, p. 161). Not only does the quality of aftercare services make a difference in the challenges that care-leavers face, but ensuring that these services actually provide what young people want is critical to uptake, as is ensuring that aftercare programmes are free of stigmatizing processes for determining eligibility (Courtney, 2019).

Despite care-leaving emerging as a topic for concern all over the world, to date, service provision has focussed mainly on the promotion of education and employment. This may well reflect the rising impact of a neoliberal agenda (Van Breda, 2019), in which young adults - including vulnerable young adults such as those transitioning out of long-term child care - are expected to fend for themselves and to take personal responsibility for obtaining work and extricating themselves from poverty (Reinders, 2016), obviating the state of its responsibility as "corporate parent" (Courtney, 2009). Alternatively, this may reflect a developmental social welfare commitment to ensuring the material needs of young people as a foundation for building personal and social well-being, manifesting in social investment and savings programmes (Conley, 2010).

It would be interesting to explore how the aftercare support that is offered is linked to social security programmes in different countries. It would be interesting also to understanding how social infrastructures (Eßer \& Schröer, 2018) are constructed in these countries in relation to legal regulations and regional policies. Comparative research that identifies the social infrastructures, including national welfare policies that care-leavers can rely on, could be a next valuable step in identifying the life course transition regimes of care-leaving in a transnational perspective (Walther, 2016).

Research on transition regimes to date has not focussed analyses on care-leaving (Cameron et al., 2018). Transition regimes research is directed to transitions to work and youth participation on the one hand and social disadvantages as a general topic (gender policies, migration, income, informal learning, etc.) on the other hand. Walther et al. (2005) explored how school systems, vocational training, unemployment policies and social security entitlements have shaped general youth transitions. They identified different youth transition regimes across Europe, reflecting "constellations of socio-economic, institutional and cultural factors that contribute to different "normalities" of being young and growing up" (Walther, Stauber, \& Pohl, 2013, p. 228). However, this work has not explored how child welfare regulations and social policies and practices interact alongside general social provisions and their implications for care-leavers. Expanding this theoretical work could be a meaningful area for further study, contributing to improved multinational comparisons of care-leaving.

Leaving care seems to be a question of social disadvantage and social inequality in almost all the countries under study, despite striking differences at the level of culture, economics and political systems. No matter what the context, transnational, national and regional social policies for care-leavers are necessary, so that they will have social prospects comparable to those of their peers in relation to the transition to adulthood. Bond (2018) argues that the absence of entitlements for care-leavers signals neglect by the state in its role as corporate parent. This topic must thus be framed as an issue of social justice.

If promoting resilience in youth who grow up in alternative care around the world is truly an important goal, we must look not only to document but to reform "multiple layers of systems, including 
culture and social structures" (Van Breda, 2019, p. 273). The Guidelines for Alternative Care (United Nations, 2010) emphasize the right for aftercare services globally. As this study indicates, these rights are only weakly upheld across countries, perhaps because they are understood as an extension of the rights for children only, which end at age 18. A significant and renewed debate - or rather, a social movement is required that champions the universal rights of care-leavers after they have turned 18 and that strongly supports them in the transition to adulthood. More comparative research can support such a movement, particularly research that documents how advocacy around the world has been successful in promoting the rights of care-leavers. One key strategy for driving that debate might be the formation of an international association of care-leavers that campaigns at a global level for reforms to promote optimal outcomes for youth from care everywhere.

Funding. No funding was received in support of this study.

\section{References}

Arnett, J. J. (2019). Foreword. In V. R. Mann-Feder \& M. Goyette (Eds.), Leaving care and the transition to adulthood: International contributions to theory, research and practice (pp. xiii-xx). Oxford, UK: Oxford University Press.

Backe-Hansen, E., Højer, I., Sjöblom, Y., \& Storø, J. (2013). Out of home care in Norway and Sweden: Similar and different. Psychosocial Intervention, 22, 193-202. https://doi.org/10.5093/in2013a23

Bond, S. (2018). Care leaving in South Africa: An international and social justice perspective. Journal of International and Comparative Social Policy, 34(1), 76-90. https://doi.org/10.1080/21699763.2017.1413994

Cameron, C., Hollingworth, K., Schoon, I., van Santen, E., Schröer, W., Ristikari, T., Heino, T., \& Pekkarinen, E. (2018). Care leavers in early adulthood: How do they fare in Britain, Finland and Germany? Children and Youth Services Review, 87, 163-172. https://doi.org/10.1016/j.childyouth.2018.02.031

Conley, A. (2010). Social development, social investment, and child welfare. In J. Midgley \& A. Conley (Eds.), Developmental social work and social development: Theories and skills for developmental social work (pp. 31-54). New York, NY: Oxford University Press.

Courtney, M. E. (2008). United States. In M. Stein \& E. R. Munro (Eds.), Young people's transitions from care to adulthood: International research and practice (pp. 225-237). London, UK: Jessica Kingsley Publishers.

Courtney, M. E. (2009). The difficult transition to adulthood for foster youth in the US: Implications for the State as corporate parent. Social Policy Report, 23(1), 1-19. https://doi.org/10.1002/j.2379-3988.2009.tb00058.x

Courtney, M. (2019). The benefits of extending care to young adults: Evidence from the United States of America. In V. R. Mann-Feder \& M. Goyette (Eds.), Leaving care and the transition to adulthood: International contributions to theory, research and practice (pp. 131-148). Oxford, UK: Oxford University Press.

Eßer, F., \& Schröer, W. (2018). Infrastrukturen der kindheiten -ein transorganisationaler zugang [Infrastructures of childhood: A trans-organisational approach]. ZSE Zeitschrift für Soziologie der Erziehung und Sozialisation, 2(39), 119-133. https://content-select.com/de/portal/media/view/5ce654c5-7d24-4280-9f8e-3671b0dd2d03

Evans, H. (2013). The impact of organisations representing children and young people in public care in the UK. Dialogue in Praxis: A Social Work International Journal, 2(15), 59-72. http://oro.open.ac.uk/id/eprint/40148

Gilligan, R. (2019). Resilience, transitions, and youth leaving care. In V. R. Mann-Feder \& M. Goyette (Eds.), Leaving care and the transition to adulthood: International contributions to theory, research and practice (pp. 51-68). Oxford, UK: Oxford University Press.

Goyette, M. (2019). Social networks and social support in the transition to adulthood: A reflection on social integration processes. In V. R. Mann-Feder \& M. Goyette (Eds.), Leaving care and the transition to adulthood: International contributions to theory, research and practice (pp. 31-50). Oxford, UK: Oxford University Press.

Harzing, A., Reiche, B. S., \& Pudelko, M. (2013). Challenges in international survey research: A review with illustrations and suggestions for best practice. European Journal of International Management, 7(1), 112-134. https://doi.org/10.1504/ EJIM.2013.052090

Havlicek, J., Lin, C. H., \& Braun, M. T. (2016). Cultivating youth voice through participation in a foster youth advisory board: Perspectives of facilitators. Children and Youth Services Review, 69, 1-10. https://doi.org/10.1016/j.childyouth.2016.07.018

Jackson, S., \& Cameron, C. (2012). Leaving care: Looking ahead and aiming higher. Children and Youth Services Review, 34(6), 1107-1114. https://doi.org/10.1016/j.childyouth.2012.01.041

Keller, S., Strahl, B., Refaeli, T., \& Zhao, C. T. (2016). Researching care leavers in an ethical manner in Switzerland, Germany, Israel and China. In P. Mendes \& P. Snow (Eds.), Young people transitioning from out-of-home care (pp. 241-261). London, UK: Springer. 
Kelly, B., Dixon, J., \& Incarnato, M. (2016). Peer research with young people leaving care: Reflections from research in England, Northern Ireland and Argentina. In P. Mendes \& P. Snow (Eds.), Young people transitioning from out-of-home care: International research, policy and practice (pp. 221-240). London, UK: Palgrave.

KESCA (Kenya Society of Care Leavers). (2015). About KESCA. https://www.kesca.org/

Mann-Feder, V. R. (2019). How can I be a real adult? Developmental theory as a framework for practice, policy, and research on care leaving. In V. R. Mann-Feder \& M. Goyette (Eds.), Leaving care and the transition to adulthood: International contributions to theory, research and practice (pp. 9-30). Oxford, UK: Oxford University Press.

Mann-Feder, V. R., \& Goyette, M. (Eds.). (2019). Leaving care and the transition to adulthood: International contributions to theory, research, and practice. Oxford, UK: Oxford University Press.

Marion, É., \& Paulsen, V. (2019). The transition to adulthood from care: A review of current research. In V. R. Mann-Feder \& M. Goyette (Eds.), Leaving care and the transition to adulthood: International contributions to theory, research and practice (pp. 107-130). Oxford, UK: Oxford University Press.

Mendes, P., \& Snow, P. (Eds.). (2016). Young people transitioning from care: International research, policy and practice. London, UK: Palgrave.

Mendes, P., \& Rogers, J. (2020). Young people transitioning from out-of-home care: What are the lessons from extended care programs in the USA and England for Australia? British Journal of Social Work, 50(5), 1513-1530. https://doi.org/10.1093/ bjsw/bcaa028

Munro, E. (2019). Reflections on upholding the rights of youth leaving out-of-home care. In V. R. Mann-Feder \& M. Goyette (Eds.), Leaving care and the transition to adulthood: International contributions to theory, research and practice (pp. 69-86). Oxford, UK: Oxford University Press.

Munro, E. R., Mølholt, A., \& Hollingworth, K. (2016). Leaving care in the UK and Scandinavia: Is it all that different in contrasting welfare regimes? In P. Mendes \& P. Snow (Eds.), Young people transitioning from out-of-home care: International research, policy and practice (pp. 199-219). London, UK: Palgrave.

Munro, E. R., \& Stein, M. (2008). Introduction: Comparative exploration of care leavers' transitions to adulthood. In M. Stein \& E. R. Munro (Eds.), Young people's transitions from care to adulthood: International research and practice (pp. 11-20). London, UK: Jessica Kingsley.

O'Higgins, A., Sebba, J., \& Gardner, F. (2017). What are the factors associated with educational achievement for children in kinship or foster care: A systematic review. Children and Youth Services Review, 79, 198-220. https://doi.org/10.1016/j. childyouth.2017.06.004

Pinkerton, J. (2008). States of care leaving: Towards international exchange as a global resource. In M. Stein \& E. R. Munro (Eds.), Young people's transitions from care to adulthood: International research and practice (pp. 241-257). London, UK: Jessica Kingsley.

Pinkerton, J., \& Van Breda, A. D. (2019). Policy as social ecological resilience scaffolding for leaving care: A case study of South Africa. In V. R. Mann-Feder \& M. Goyette (Eds.), Leaving care and the transition to adulthood: International contributions to theory, research and practice (pp. 87-104). Oxford, UK: Oxford University Press.

Raychaba, B. (1989). Canadian youth in care: Leaving care to be on our own with no direction from home. Children and Youth Services Review, 11(1), 61-73. https://doi.org/10.1016/0190-7409(89)90007-8

Reinders, H. (2016). Vom bildungs- zum optimierungsmoratorium [From moratorium on education to optimization]. Diskurs Kindheits- und Jugendforschung, 11(2), 147-160. https://doi.org/10.3224/diskurs.v11i2.23652

Refaeli, T., \& Strahl, B. (2014). Turning point processes to higher education among care leavers. Social Work \& Society, 12(1) 1-13. https://www.socwork.net/sws/article/view/388

Reiche, B. S., \& Harzing, A. (2007). Key issues in international survey research. Harzing.com: Research in International Management. https://harzing.com/publications/white-papers/key-issues-in-international-survey-research

Sanders, J., \& Munford, R. (2014). Youth-centred practice: Positive youth development practices and pathways to better outcomes for vulnerable youth. Children and Youth Services Review, 46, 160-167. https://doi.org/10.1016/j.childyouth.2014.08.020

Stein, M. (2008). Transitions from care to adulthood: Messages from research for policy and practice. In M. Stein \& E. R. Munro (Eds.), Young people's transitions from care to adulthood: International research and practice (pp. 289-306). London, UK: Jessica Kingsley.

Stein, M., \& Dumaret, A. (2011). The mental health of young people aging out of care and entering adulthood: Exploring the evidence from England and France. Children and Youth Services Review, 33(12), 2504-2511. https://doi.org/10.1016/j. childyouth.2011.08.029

Stein, M., \& Munro, E. R. (Eds.). (2008). Young people's transitions from care to adulthood: International research and practice. London, UK: Jessica Kingsley.

Storø, J. (2015). From superintendence to transition and self-determination: Historic view on policies and practice towards Norwegian care-leavers. Practice, 27(1), 5-20. https://doi.org/10.1080/09503153.2014.970156

Storø, J., Sjöblom, Y., \& Höjer, I. (2019). A comparison of state support for young people leaving care in Norway and Sweden: Differences within comparable welfare systems. Child \& Family Social Work, 24(3), 393-399. https://doi.org/10.1111/ cfs. 12471 
Ubbesen, M.-B., Gilbert, R., \& Thoburn, J. (2015). Cumulative incidence of entry into out-of-home care: Changes over time in Denmark and England. Child Abuse \& Neglect, 42, 63-71. https://doi.org/10.1016/j.chiabu.2014.10.006

United Nations. (2010). Guidelines for the alternative care of children. Geneva, Switzerland: United Nations General Assembly. Van Breda, A. D. (2018). Research review: Aging out of residential care in South Africa. Child and Family Social Work, 23(3), 513-521. https://doi.org/10.1111/cfs.12431

Van Breda, A. D. (2019). Reclaiming resilience for social work: A reply to Garrett. British Journal of Social Work, 49(1), 272-276. https://doi.org/10.1093/bjsw/bcy010

Van Breda, A. D., \& Pinkerton, J. (2020). Raising African voices in the global dialogue on care-leaving and emerging adulthood. Emerging Adulthood, 8(1), 6-15. https://doi.org/10.1177/2167696819870356

Walther, A. (2016). Support across life course regimes: A comparative model of social work as constructions of social problems, needs, and rights. Journal of Social Work, 17(3), 277-301. https://doi.org/10.1177/1468017316640195

Walther A., Pohl, A., Biggart, A., Julkunen, I., Kazepov, Y., \& Kovacheva, S. (2005). Thematic study on policy measures concerning disadvantaged youth. Tübingen, Germany: Institute for Regional Innovation and Social Research. https:// ec.europa.eu/employment_social/social_inclusion/docs/youth_study_en.pdf

Walther, A., Stauber, B., \& Pohl, A. (2013). Support and success in youth transitions: A comparative analysis on the relation between subjective and systemic factors. In A. M. Minguez (Ed.), Family well-being: European perspectives (pp. 225-241). Dordrecht, The Netherlands: Springer.

Ward, H. (2008). Legal and policy frameworks. In M. Stein \& E. R. Munro (Eds.), Young people's transitions from care to adulthood (pp. 258-278). London, UK: Jessica Kingsley.

Cite this article: Strahl, B. van Breda, A.D.P. Mann-Feder, V. and Schröer, W. (2021). A multinational comparison of careleaving policy and legislation. Journal of International and Comparative Social Policy 37: 34-49. https://doi.org/10.1017/ ics.2020.26 